\title{
学術・技術論文
}

\section{同期キャスタ駆動機構によるホロノミック全方向移動ロボットの 設計と運動解析}

\author{
和 田 正 義*

\section{Design and Analysis of a Wheeled Platform with a Synchro Caster-drive Mechanism for Holonomic and Omnidirectional Mobile Robots}

\author{
Masayoshi Wada*
}

\begin{abstract}
A new vehicle assembly for holonomic and omnidirectional mobile robots is presented. A caster-drive mechanism is one of the feasible solutions to allow a holonomic omnidirectional vehicle to equip standard wheels for its driving wheels. A traditional synchro-drive transmission is applied to the caster-drive system. Multiple drive-caster wheels are mechanically coupled and simultaneously driven and steered by respective motors. A rotational stage, orienting a vehicle frame, is attached on the center top of the mobile base. Position and translational velocities of the mobile base are controlled by the synchronized drive-casters. The orientation of the vehicle frame is controlled by the rotational stage completely decoupled from the translational motion of the mobile base. The synchro-drive transmission brings enormous advantages to the holonomic vehicle; three motor driven, all wheel drive, decoupling control, and simpler mechanism. In addition, an offset gear drive is also applied to the drive-caster wheel. This gear transmission enables a decoupling control of the drive shaft from the steering shaft on each wheel. By applying those mechanisms, the vehicle kinematics becomes very simple. Kinematics and statics of the proposed omnidirectional vehicle are analyzed and verification of the mechanism is shown by computer simulations.
\end{abstract}

Key Words: Holonomic and Omnidirectional Vehicle, Caster Drive, Over-constraint, Synchro-drive, Decoupled Gear Transmission

1.はじめに

車輪移動型ロボットは，エネルギー効率が高く，機構および 制御上簡易であることから，整地での移動においては歩行式の 移動機構などに比較して実用的であり，現状移動システムとし て最も普及している方式である，車輪型移動ロボットのなかで もホロノミックな移動特性を持つものは, 自動車型などの非ホ ロノミックな車両に比較して高度な移動特性を持つものとして 知られている.このタイプの車両では操作性向上 $[1]$, 軌道計画 や車両制御系の簡単化，線形フィードバック制御による車両の 制御 [2], あるいはマニピュレー夕の研究により蓄積された現代 制御の適用 [3] などが可能であり，多くの利点がある.

これらホロノミックな特性を有する移動機構の研究において は，多くの形態の車両が提案されてきた [4]〜 [8]. しかし，これ らはその動輪に駆動力の発生方向と直交する方向に受動的に転 がることができる機構，あるいは機能を備えた特殊な形態の車 輪を必要とする，その代表的なものとして，駆動車輪の円周に

原稿受付 2000 年 9 月 18 日

*(株) 富士電機総合研究所

${ }^{*}$ Fuji Electric Corporate Research and Development, Ltd.
沿って車輪の横方向，あるいは 45 度の方向に自由に回転する 多数のローラを取り付けたユニバーサルホイールあるいはメカ ナムホイールと呼ばれる車輪や, 球形の車輪を用いるものなど がある.しかし，これらの車輪機構はその機構の複雑さのみな らず，走行時の振動や耐荷重の低下，走破できる段差の高さの 限界などの問題が指摘されている [9]. ホロノミックな全方向移 動ロボットには前述のような利点があるにもかかわらず, 研究, 教育用などを除く実用の移動車両にこの移動性を持つものがあ まり見受けられない。これは，車輪の構造やその耐久性などの 実用段階での課題がまだ残されており，ホロノミックな移動特 性による利点よりも，これらの欠点の方がその事実上問題視さ れていることが要因ではないかと推測される.

これらの車輪構造に起因する問題点を解決するため, 通常の タイヤを装着できるキャスタ型の駆動輪を用いた全方向移動車 両が筆者のグループにより提案され [10], さらに数種類の形態 が開発されている。しかし，これらの移動システムにもまだ問 題点が残されており検討, 改善の必要がある.

本文では, キャス夕駆動の原理を基本とし, 三つのアクチュ エータにより制御可能である全輪駆動型のホロノミックな全方 向移動車両を提案し, その運動特性について考察する。この移 
動機構には単輪キャスタを変形した形態の駆動輪を用い，その 車輪の回転と，操舵をそれぞれ独立なアクチュエー夕により制 御する。この車輪機構では, 車輪の転がり方向のみならず, 車輪 の横方向にも距離を隔てた位置に操舵軸を配置し, 双輪キャス 夕の一輪を取外したような形態を有する。移動べースにはこの 車輪を複数搭載し，すべての車輪，およびすべての操舵をそれ ぞれ単一のアクチュエータによって同期して駆動させる。これ は従来の非ホロノミック移動ロボットに用いられてきた同期駆 動機構 (Synchro-drive Transmission) に類似した構造により 複数のキャス夕型の動輪を駆動するものである。移動べースの 水平面上の位置と並進速度は，この複数のキャス夕型動輪を同 期駆動する二つのアクチュエータにより制御できる。ささに、移 動ベースには車両本体を旋回させるための第三のアクチュエー 夕を備え, 移動ベース上にて車両本体を旋回駆動させることに より車両の姿勢, 旋回速度が制御できる。この車両構造によれ ば，車輪の転がり方向，横方向の速度，および車両の旋回速度 それぞれが三つのアクチュエータにより運動学的に完全に独立 して駆動させることが可能となる。また，アクチュエー夕の数 を増加させることなく全輪を駆動輪とすることができ，車輪数 の選択も自由であることから，車輪の幅を薄くすることで車両 の走行精度を向上させ，車輪数を増やすことで，車両の耐荷重 を向上させることができる。また，車輪の搭載位置にも制約が 少ないことから, 車両設計の自由度も高い.

以下本文では，2 章においてこれまでに開発されたキャス夕 型動輪を用いた全方向移動車両について考察し, それらの問題 点を指摘する．次に 3 章では新しい駆動方式に基づく全方向移 動車両を提案し，4章においてはその車輪機構，および車両の 運動学モデルを導出し, 簡単な形態のモデルが得られることを 示す.また, 静力学の解析を 5 章にて行い, 力学的にモータト ルクの静的干渉がなく, モータの小容量化が可能であることを 示す. 6 章では, 導出した連動学モデルに基づいたシミュレー ションにより提案した機構の運動制御の有効性を確認し， 7 章 において結論を述べる。

\section{2. キャスタ型動輪機構を用いた全方向移動車両}

\section{1 キャスタ型動輪機構を用いた全方向移動車両}

Fig. 1 は筆者らにより提案されたキャス夕型動輪機構（オフ セット駆動輪）を用いた全方向移動車両の模式図である [10]. こ の車輪機構は, 操舵軸から車輪の転がり方向に一定距離隔てた 位置に標準的な車輪が取り付けられた通常のキャス夕と同様な 形態を有する。また，本機構では車輪軸と操舵軸をそれぞれ独 立なアクチュエータにて駆動する。ここでこの車輪の制御方法 について簡単に説明する。この車輪機構の制御の目的はその操 舵軸の中心に任意の方向へ任意の大きさの速度べクトルを発生 させることである，まず，車輪軸のみを角速度 $\omega_{w}$, で回転させ たときには，操舵軸中心には車輪の転がり方向への速度 $v_{w}$ が 発生する. 一方, 操舵軸のみを角速度 $\omega_{s}$ にて回転させたとき には，操舵軸は車輪の接地点を中心とした円運動を行うことか ら, 操舵軸中心には円の接線方向, つまり車輪の横方向への速 度 $v_{s}$ が発生する.これらの各速度べクトルは車輪の姿勢にか かわらず常に直交するので，これら二つの速度，つまり，車輪

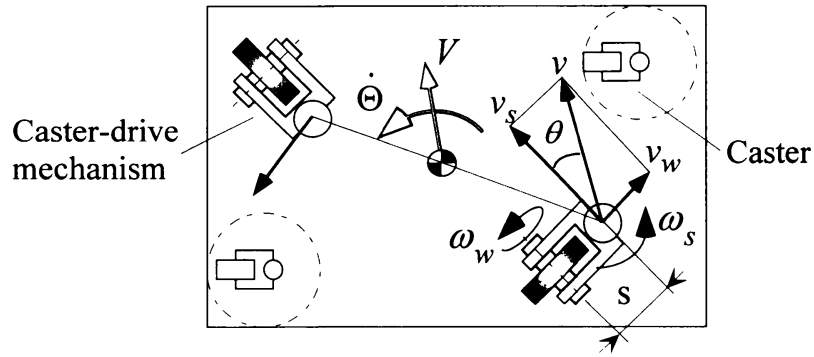

Fig. 1 Vehicle with single-wheel caster mechanisms

の回転と車輪の操舵を独立に制御することで, 操舵軸中心に発 生する合成べクトル $v$ の大きさとその方向 $\theta$ を任意に制御す ることが可能となる．全方向車両にはこの形態の車輪を二つ以 上搭載し, 車両に対して任意の並進速度 $V$ と, 任意の回転速度 $\dot{\Theta}$ を同時に与えることができる.

また，双輪キャス夕型の車輪機構を二つ以上用い，それぞれ の機構の二つの車輪を独立に駆動することで，上述の全方向移 動ロボットと類似の原理にてホロノミックな動作を実現する車 両も提案されている [11]〜 [13].

これらの車両システムでは空気圧タイヤやゴムタイヤのよう な標準的な車輪を用いてホロノミックな全方向移動車両を構成 できる反面，少なくとも四つのモー夕を使用しなくてはならず， 圥長駆動になることが欠点として挙げられる。これは多くの駆 動輪を搭載する場合に特に顕著となる．例えば 4 輪の全輪駆動 車両を考えると，8個ものモータが必要となる [14]. このとき には 5 自由度が圥長となり, 車両の制御システムは複雑で大規 模なものにならざるを得ない。また，システム立ち上げ時のよ うな各車輪の操舵角を知ることができない状態では車両は一切 動作させることができないことも問題となる，つまり，一般の 機械で行われている原点出しの動作を行うことができない.こ のことから, 各駆動輪ごとに操舵軸の車両本体に対する角度を 計測する絶対值エンコーダなどが必須となる。

さらにこの形態の車輪の実際の設計においては，連続的な 多回転運動が操舵軸に要求されるため, 配線などの問題から車 輪用，操舵用いずれのモー夕も車両本体側に搭載される場合が 多い.このとき, 車輪の駆動力は歯車などの伝達機構を介して 車輪軸まで伝えられるが, 操舵の運動と車輪の運動が干渉する という問題が発生する.これは次の二種類の現象としてとらえ られる。

一つは操舵用のモー夕速度から車輪の回転速度への速度干渉 で，操舵軸のみを回転させたときに，車輪はその向きを変化さ せると同時に車輪自身も回転してしまうものである。この速度 干渉は操舵用モー夕のある割合の回転が車輪の回転に重合され るということから起こり, 車輪用モー夕を停止していない状態 においても同様に発生する。この速度干涉の割合は動力伝達機 構の減速比により一意の定数として決まるので, 車輪用モー夕 に操舵軸用モー夕の回転数のある比率分を加減算した速度指令 を与えることで対処できる．しかしこの方法では操舵軸のサー ボ誤差などを補償することはできない.

もう一つは, 車輪用モータから操舵軸へのトルク干渉である. 


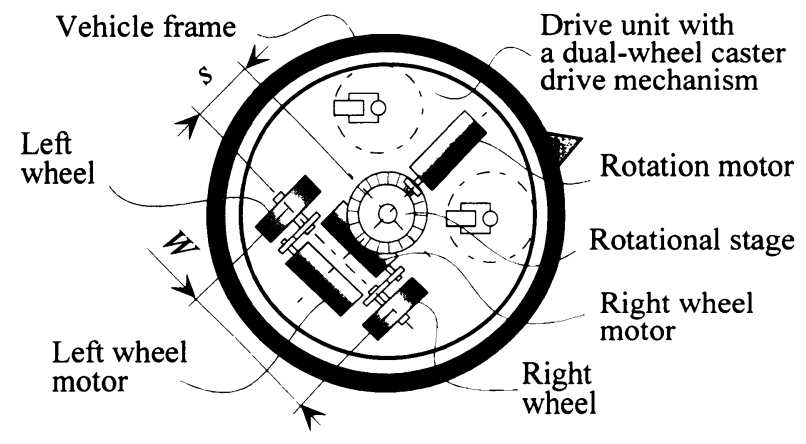

Fig. 2 Vehicle with a dual-wheel caster mechanism

車輪用モー夕は操舵軸用の伝達機構の途中の歯車や, 操舵軸に 固定された部材を支点として駆動トルクを車輪に伝達するので, 操舵用モー夕はこれを支えるだけのトルクを発生しなければな らない。これは段差などを乗り上げる瞬間のような車輪用モ一 夕が特に大きなトルクを車輪に伝えようとするときに問題とな り, このトルク干涉が操舵軸のサーボ誤差の要因ともなる。こ れら二つの現象は, 必要以上に早い回転速度を車輪用モー夕に, また大きいトルクを操舵用のモー夕にそれぞれ要求することに なり, 両モー夕の容量を増大させる結果となる。

2.2 双輪キャスタ型動输機構を一つ用いた全方向移動車両

これは双輪キャスタと同様の軸構成を有する動輪機構を一つ 用いた全方向車両である [15]〜 [17]．Fig. 2 に模式図を示す．駆 動ユニットには平行な 2 輪の駆動輪を搭載し，それぞれ独立な モータにより回転駆動させる。ささらに駆動ユニット上の車輪の 中点から車輪の転がり方向へ一定距離隔てた位置に操舵軸を搭 載し，第三のモータにより回転駆動させることで駆動ユニット 上にて車両本体を旋回運動させる。つまり，従来の 2 輪速度差 駆動ユニット上の偏心した位置に操舵軸を追加し, 車両本体を 水平旋回させる構造である。この機構では，上述の単輪キャス 夕の駆動原理と同様にして，2 輪速度差機構の旋回運動により 操舵軸の横方向の速度を制御し, 直進運動により前後方向の速 度を制御する。また，車両本体の回転は操舵軸を駆動する第三 のモータにより制御する。このように三つのモー夕にて車両を 制御できることから，過拘束つまり圥長駆動の問題は解決でき る。また，機構的には簡易である反面，駆動輪は 2 輪に限定さ れることから接地面積の確保に限界があり，また車両の支持に 受動輪を使用せざるを得ないという欠点がある。このことより， 大型の車両への適用には限界がある。ささらに並進運動を行う際 に駆動ユニット自身が回転運動を伴うことから，車両本体の姿 勢を制御するためにはこの駆動ユニットの回転を補償しなけれ ばならず，操舵軸駆動用モータとして必要以上の大きな回転速 度を発生できるものを選定しなくてはならない。

以上より第一の形態の車両では朵長駆動とモー夕間の干涉が 問題であり，第二の形態では 2 輪に限定された設計に起因する 問題があることが分かった。

\section{3. 同期キャスタ駆動機構による全方向移動車両}

本章ではこれまで開発したキャス夕型動輪機構を用いた車両

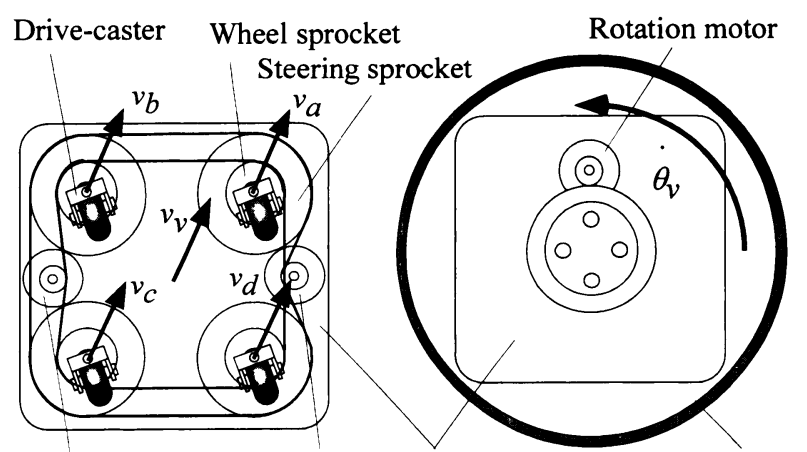

Wheel motor Steering motor Mobile base Vehicle frame

$\begin{array}{ll}\text { (a) Synchro-drive transmission } & \text { (b) Rotational stage }\end{array}$

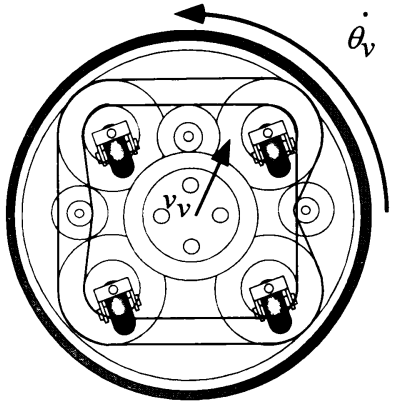

(c) Holonomic vehcile with synchro caster-drive system

Fig. 3 Synchro-drive train for caster-drive mechanism

の問題点を解決するために二つの対策を講じる。一つは同期駆 動機構の導入であり，一つは車輪の非干渉機構の導入である。こ れらはいずれも従来の全輪操舵型の非ホロノミック移動車両に 適用されている機構であるが，以下に検討するようにキャス夕 型動輪に適用した場合には，前述の問題を解決するのみならず， これらの機構が有するさまざまな利点を利用しホロノミック車 両を構成することができる。

\section{1 同期駆動機構（Synchro-drive Mechanism）}

同期駆動機構は，従来の非ホロノミックな移動ロボットに広 く使用されている [18].この機構は，二つのアクチュエータに より複数の車輪の回転と車輪操舵を行うもので, 搭載するアク チュエー夕の数を増加させることなく, 車輪の総接地面積や車 両の安定性を增す目的に有効な機構である。

従来の同期駆動機構には二つのモータが搭載され，通常の操 舵車輪の回転と操舵が制御できる。操舵用モータにより車輪と 同時に車両本体を旋回駆動することで車而本体は常に車輪の走 行方向を向く．ホロノミック全方向移動車両にこの同期駆動機 構を適用するには, 車輪の形態をキャスタ型の車輪とし, さら に車両の旋回制御用に第三のモー夕を追加し, 移動ベース上に て車両本体を独立に旋回させる。キャス夕型車輪の回転，およ び操舵を行う二つのモータを 2.1 節において説明したキャス夕 駆動の原理により制御することで，車両の並進運動を制御し， 旋回用モー夕によって車両本体の旋回を行うことでホロノミッ クな動作が可能となる。単輪キャス夕型動輪を同期駆動する機 構の概念図を Fig. 3 (c) に示す. 同期駆動機構の特徵は, 車輪 の滑りがない限り, 複数の車輪を搭載する移動ベースが床に対 して旋回運動を行わないことである．各車輪が同期駆動される 
結果, すべての操舵軸中心には同一の速度ベクトルが発生され るため，移動べースは姿勢を一定にしたまま全方向移動を行う Fig. $3(\mathrm{a})$.つまり，床に対して平行移動のみを行う。このため， 移動ベースに搭載される車両本体の旋回を行うモー夕は, 車両本 体の旋回運動が要求されるときのみ動作すればよいFig. $3(\mathrm{~b})$. その結果，双輪キャス夕型動輪を一つ用いた車両のように必要 以上の回転速度を発生する旋回用モー夕を搭載する必要はなく, 車两の並進運動と回転運動を運動学的に完全に非干涉化するこ とができる。

また，本機構を用いた場合には，車両本体に対する車輪の角度 が計測できれば車両の運動は制御できるので, 絶対值エンコー ダは車両に一つ搭載すればよい。また，初期化時にロボット本 体の旋回を許容できる適用分野であれば，電源投入時にロボッ 卜本体を一回転させることで，原点出しを行うことができるの で，通常の積算型エンコーダにて車両を構成することも可能で ある。

3.2 非干渉動輪機構 (Decoupled Gear Transmission) 2.1 節にて述べた単輪キャス夕型動輪機構における車輪用モー 夕と, 操舵用モータの干涉の問題を解決するために非干渉機構 を導入する。単輪キャス夕型動輪機構は車輪の非ホロノミック 拘束 (車輪の横方向の速度は常に零) を回避する目的で, 操舵軸 から車輪の転がり方向へ距離を隔てた位置に車輪が配置されて いる，本節では，車輪の転がり方向のオフセット距離は一定に 保ち, さらに車輪の横方向にもある距離を隔てた位置に車輪を 配置することで，キャス夕型動輪の移動特性を保持しつつ, 操 舵と車輪の干涉を除去することができる車輪機構を導入する.

従来の操舵動輪に対する操舵一車輪の干渉を除去する機構は, 中野ら [19]によって提案された。その主目的は，すえきりと呼 ばれる, 車輪が回転しない状態における車輪操舵を回避すること で, 車両の停止状態における全輪操舵時の車両の摇動を軽減し, かつ操舵用モータの小型化を図ることであった。しかし，この 機構のもう一つの利点は操舵用, 車輪用の各モー夕の回転が運 動学的に非干渉化されることである。キャス夕型動輪を用いた 全方向移動車両においては，車輪が回転しない状態での操舵動 作は瞬間的にしか起こらないが，車輪，操舵の非干涉化を主目 的としてこの機構の原理を適用する。キャス夕型車輪に同様な 非干渉機構を導入した研究は他にも報告されているが $[20], こ$ れは非干渉機構を独立な駆動輪に適用し，3 輪車両を構成して いるものである。これに対し本章では非干涉車輪機構とキャス 夕型車輪の同期駆動を併用することで，より効率的な駆動を実 現する車両の構成を検討する。

Fig. 4 にキャスタ型非干涉動輪機構の模式図を示す。車輪に 対し, 車輪の転がり方向に $s$, 車輪の横方向に $d$ 離れた位置に 操舵軸を配置する.上部の車輪スプロケット, 操舵スプロケッ トは, ベルトなどの伝達機構によっておのおののモータで回転 駆動する．車輪スプロケットの軸は操舵スプロケットの中心を 貫通しており, 操舵軸と共に旋回運動するべベルギア, 平㐘車 を介して車輪に駆動トルクを伝える。また, 操舵スプロケット を回転させることで, ベベルギア, 平歯車, と共に車輪を旋回 運動させる。この構造は, 従来の非ホロノミック車両用の車輪 に平歯車を追加し, 車輪の転がり方向へ距離を隔てて操舵軸を

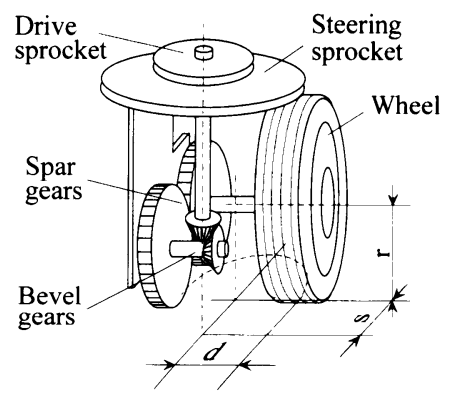

Fig. 4 Caster-drive mechanism with offsets in longitudinal s and in lateral $d$

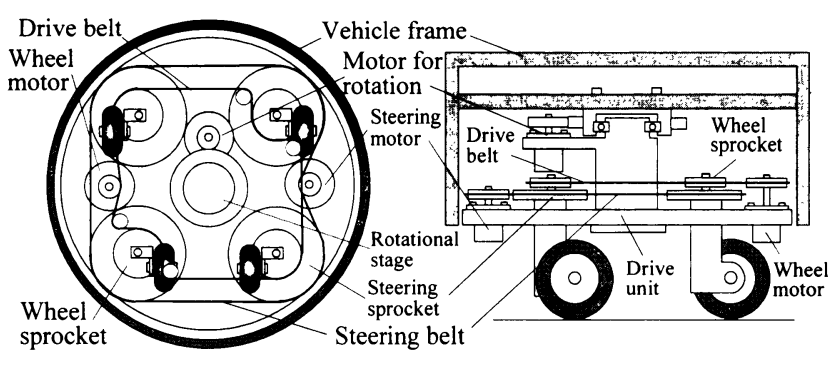

(a) Top view

(b) Side view

Fig. 5 Vehicle with a synchro-caster drive mechanism

配置することで実現できることから，機構的に簡易であること が分かる.

この非干涉車輪機構の問題点は, 車輪が操舵軸に対して横方 向に距離を持つため, 床や段差などから車輪にかかる外力が操 舵軸に作用することである．特に段差に接触する際などの特に 大きな衝撃力が作用する場合に，操舵用モー夕に大きな外乱卜 ルクを与えることとなる．4 章にて検討するように，この非干渉 車輪機構においては, 車輪, 操舵をそれぞれ単一のモータで駆 動する同期駆動において，車輪は操舵軸に対していずれの側に も配置し同期駆動することが可能である。この性質を利用して 同期駆動機構とキャス夕型非干涉動輪を併用することにより操 舵軸にかかるトルクを相殺することができる．Fig. 5 に各車輪 が互いに隣り合う車輪と逆の車輪構造を有する全方向移動車両 の模式図を示す，適用する車両は全方向移動を行うので，左右 方向に移動するときにも隣り合う車輪の構造が逆になることが 望ましい．そこで，一方の対角に位置する車輪の構造を同一の ものとし, 他の対角に位置する車輪の構造は他方と逆のものと する構成が考えられる。ここで, 一方の構造の車輪の車輪スプ ロケットは他構造の車輪機構と逆方向に駆動しなければならな い点に注意を要する. 同四の構造であれば，いずれの方向に移 動する際にも隣り合う車輪同士は異なった構造になる。ここで 例えば，同図中の上方の二車輪が段差の縁などに接触する状態 を考える。このとき，車輪に作用する段差からの衝撃力により 操舵軸に発生するモーメントは左上の車輪では操舵軸を CCW 方向に, 右上の車輪では $\mathrm{CW}$ 方向に回転させるようにそれぞ れ作用し互いに逆方向となる。ここで, 両車輪の操舵駆動軸は ベルトなどのような伝達機構で結合されているので, それぞれ 逆力向にこれらを回転させようとする結果, 発生トルクは内力 
として相殺されモータには伝達されない，以後この構造の車輪， および車両について検討する。

\section{4. 運動学解析}

\section{1 非干渉キャスタ動輪機構}

Fig. 6 にキャス夕型非干涉動輪機構の模式図を示す。ここで, 上面図において車輪が操舵軸に対して左側に配置された構造を 左配置車輪と呼ぶこととする. 車輪の転がり方向に $s$, 横方向 にdだけ車輪から離れた位置に操舵軸が配置されている。ここ で車輪座標系は操舵軸中心に原点が位置し，X 軸が車輪の転が り方向に向くように設定する.このときの車輪機構の運動は車 輪座標系における各軸方向への瞬間並進速度, および原点周り の瞬間回転角速度 $\left(\dot{x}_{w}, \dot{y}_{w}, \dot{\theta}_{w}\right)$ で表される. 車輪スプロケット を固定した状態で, 操舵スプロケットを角速度 $\omega_{s}$ にて駆動し たときを考えると，車輪は姿勢を变化させながら回転を行うこ とから, 夕イヤ単体の転が方向の速度 $v_{w}$, および姿勢の変化 率 $\dot{\phi}_{w}$ は,

$$
\begin{aligned}
v_{w} & =-r \omega_{w}=-\frac{r}{G} \omega_{s} \\
\dot{\phi}_{w} & =\omega_{s}
\end{aligned}
$$

とそれぞれ得られる。ここで, $r, \omega_{w}, G$ はそれぞれ車輪半径, タイヤの回転角速度, ベベルギアと平㐘車により構成される操 舵軸と共に旋回する部分の伝達機構の隇速比である. 一方, 操 舵軸を固定した状態にて車輪スプロケットのみを角速度 $\omega_{w}$ に て駆動した場合には，タイヤのみが $r / G \omega_{w}$ にて回転する，以 上から, キャス夕型非干涉動輪機構における車輪スプロケット, 操舵スプロケットの回転に対する夕イヤの転がり方向の並進速 度 $v_{w}$, および旋回速度 $\dot{\phi}_{w}$ は以下で与えられることが分かる。

$$
\left[\begin{array}{c}
v_{w} \\
\dot{\phi}_{w}
\end{array}\right]=\left[\begin{array}{cc}
\frac{r}{G} & -\frac{r}{G} \\
0 & 1
\end{array}\right]\left[\begin{array}{l}
\omega_{w} \\
\omega_{s}
\end{array}\right]
$$

次に, タイヤが床に対して並進速度 $v_{w}$, および旋回速度 $\dot{\phi}_{w}$ に て運動するときの操舵軸中心に発生する速度を考える. Fig. 6 (b) より, 車輪速度, 旋回角速度と, 操舵軸中心における各方向の 速度, および姿勢の变化率との関係は,

$$
\begin{aligned}
& \dot{x}_{w}=v_{w}+L \dot{\phi}_{w} \sin \psi \\
& \dot{y}_{w}=L \dot{\phi}_{w} \cos \psi \\
& \dot{\theta}_{w}=\dot{\phi}_{w}
\end{aligned}
$$

となる.ここで, 同図より $L \sin \psi=d, L \cos \psi=s$ であるこ とに注意すると, 式 (3) は簡単化され行列の形式で表現すると 以下のようになる。

$$
\left[\begin{array}{c}
\dot{x}_{w} \\
\dot{y}_{w} \\
\dot{\theta}_{w}
\end{array}\right]=\left[\begin{array}{cc}
1 & d \\
0 & s \\
0 & 1
\end{array}\right]\left[\begin{array}{c}
v_{w} \\
\dot{\phi}_{w}
\end{array}\right]
$$

式 (2),(4)より，操舵スプロケット，車輪スプロケットの回 転と, 車輪機構の運動との関係を求めると以下を得る.

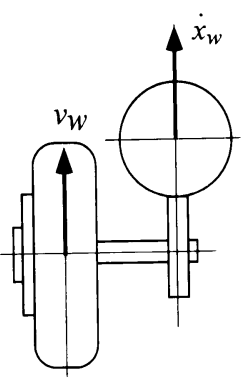

(a) Wheel traveling

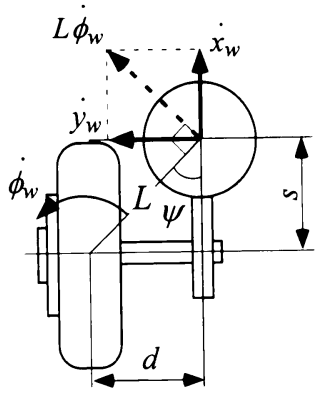

(b) Wheel steering
Fig. 6 Decoupled caster-drive mechanism

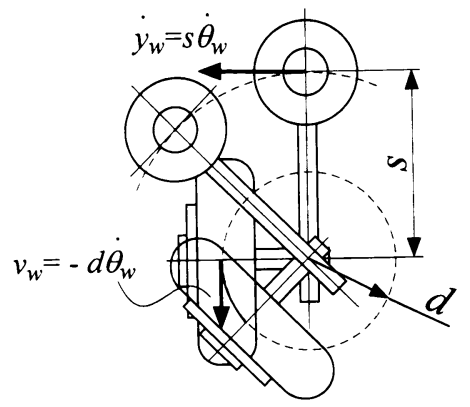

Fig. 7 Steering motion of the caster-drive mechanism with a decoupled gear transmission

$$
\left[\begin{array}{c}
\dot{x}_{w} \\
\dot{y}_{w} \\
\dot{\theta}_{w}
\end{array}\right]=\left[\begin{array}{cc}
\bar{G} & -\frac{r}{G}+d \\
0 & s \\
0 & 1
\end{array}\right]\left[\begin{array}{c}
\omega_{w} \\
\omega_{s}
\end{array}\right]
$$

ここで, 車輪駆動軸と, 操舵駆動軸の非干涉化を行うためには, 右辺の行列の 1 行 2 列の要素を零にすればよいことから, 非干 渉化の条件は以下で与えられる。

$$
d=\frac{r}{G}
$$

これを代人すると, 最終的なキャス夕型非干渉動輪機構の運動 式は以下のように簡単な形で与えられる.

$$
\left[\begin{array}{c}
\dot{x}_{w} \\
\dot{y}_{w} \\
\dot{\theta}_{w}
\end{array}\right]=\left[\begin{array}{ll}
d & 0 \\
0 & s \\
0 & 1
\end{array}\right]\left[\begin{array}{l}
\omega_{w} \\
\omega_{s}
\end{array}\right]
$$

以上より, 通常の操舵輪に用いられてきた非干渉機構がキャ ス夕型車輪にも適用可能であり, 式 (6) の設計条件を渵たすと き非干涉化が可能であることが分かった。この車輪機構が操舵 動作を行う様子を Fig. 7 に示す. タイヤ，および操舵軸は操舵 軸から夕イヤの転がり方向に $s$ 離れた点を中心にそれぞれ半径 $d$ および $s$ にて回転する.

また, 右配置の車輪の運動学モデルも式 $(1) \sim(7)$ と同様の 手順にて以下のように求められる.

$$
\left[\begin{array}{c}
\dot{x}_{w} \\
\dot{y}_{w} \\
\dot{\theta}_{w}
\end{array}\right]=\left[\begin{array}{cc}
-d & 0 \\
0 & s \\
0 & 1
\end{array}\right]\left[\begin{array}{c}
\omega_{w} \\
\omega_{s}
\end{array}\right]
$$




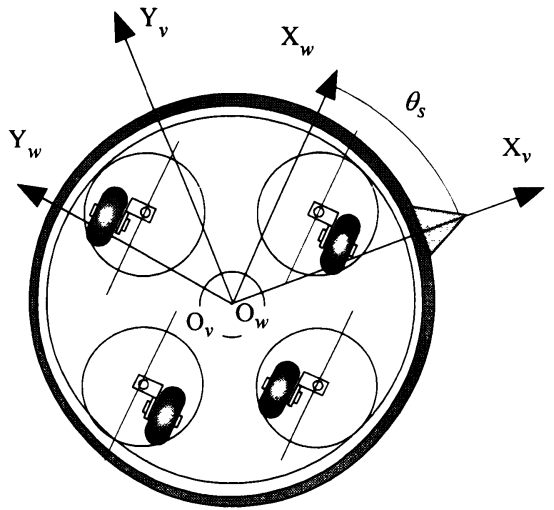

Fig. 8 Coordinate system on the vehicle with synchro casterdrive mechanism

\subsection{4 輪車両}

4 輪車両の座標系設定を Fig. 8 に示す。車両本体座標系 $\Sigma-O_{v} X_{v} Y_{v}$ は車両中心にその原点を一致させ，また $\mathrm{X}$ 軸 を車両前方に向くように設置する。車輪座標系 $\Sigma-O_{w} X_{w} Y_{u}$ は 4 輪の座標系を一つに統一し，その原点を車両中心に一致さ せ，かつそのX 軸が車輪の進行方向に向くように設置する。こ こで，車両本体座標系の X 軸と車輪座標系の X 軸とのなす角度 を $\theta_{s}$ とする．移動ベースには車輪が 4 輪搭載されている．右 配置, 左配置の車輪の運動学モデルは式 (7),（8）のように異 なった形式になるが，Fig. 5 に示すように右配置車輪の車輪ス プロケットの駆動方向を逆にすることで式（7）に統一できる. このとき駆動ユニットに搭載されるすべてのキャス夕型動輪は 大きさ，方向とも等しい速度を発生するので駆動ユニットは床 に対してあらゆる方向への平行移動を行う。この結果, 車両本 体は操舵軸の回転によってのみ旋回運動を行うことになる。こ れから車両本体の車両座標系の各方向への移動速度 $\dot{x}_{v}, \dot{y}_{v}$ お よび旋回 $\dot{\theta}_{v}$ は以下で与えられる。

$$
\left[\begin{array}{c}
\dot{x}_{v} \\
\dot{y}_{v} \\
\dot{\theta}_{v}
\end{array}\right]=\left[\begin{array}{ccc}
d \cos \theta_{s} & -s \sin \theta_{s} & 0 \\
d \sin \theta_{s} & s \cos \theta_{s} & 0 \\
0 & 0 & 1
\end{array}\right]\left[\begin{array}{c}
\omega_{w} \\
\omega_{s} \\
\omega_{r}
\end{array}\right]
$$

ここで得られた右辺の $3 \times 3$ の正方行列は車両のヤコビ行列 Jである。この行列式は零でないことから，逆ヤコビ行列 $\mathbf{J}^{-1}$ は容易に求められ，車両の逆運動学モデルは以下のようになる。

$$
\left[\begin{array}{c}
\omega_{w} \\
\omega_{s} \\
\omega_{r}
\end{array}\right]=\left[\begin{array}{ccc}
\frac{\cos \theta_{s}}{d} & \frac{\sin \theta_{s}}{d} & 0 \\
-\frac{\sin \theta_{s}}{s} & \frac{\cos \theta_{s}}{s} & 0 \\
0 & 0 & 1
\end{array}\right]\left[\begin{array}{c}
\dot{x}_{v} \\
\dot{y}_{v} \\
\dot{\theta}_{v}
\end{array}\right]
$$

以上より, 車両の運動学, および逆運動学は圥長駆動のない 非常に簡単な形式となり，またいかなる $\theta_{s}$ に対しても計算可 能であることから特異点は存在しないことが分かる。

\section{5. 静 力 学}

5.1 キャスタ型非干渉動輪機構

ここではキャス夕型非干涉動輪機構の静力学を解析する．移

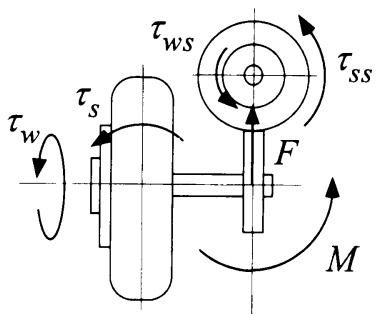

Fig. 9 Force/torque relationships on the wheel

動ロボットの動作はマニピュレータの動作と比較して低速であ ることから静力学は車両設計においてアクチュエー夕の基本的 な選定基準となる。

まず, 車輪スプロケットと, 操舵スプロケットの間に作用す るトルクについて考察する. 式 (2) から，各スプロケットの回 転トルクと車輪に直接作用する車輪軸トルク，操舵卜ルクとの 間の関係は以下のように求められる.

$$
\left[\begin{array}{c}
\tau_{w s} \\
\tau_{s s}
\end{array}\right]=\left[\begin{array}{cc}
\frac{r}{G} & 0 \\
-\frac{r}{G} & 1
\end{array}\right]\left[\begin{array}{c}
\frac{\tau_{w}}{r} \\
\tau_{s}
\end{array}\right]
$$

ここで $\tau_{u s s}, \tau_{s s}$ はそれぞれ車輪スプロケットと操舵スプロケッ トの回転トルクであり， $\tau_{w}, \tau_{s}$ は車輪軸トルクおよび操舵トル クである.ここで，Fig.9に示すように車輪機構が $F$ の力と， $M$ のモーメントで駆動されているとすると以下の関係が成立 する.

$$
\begin{aligned}
\frac{\tau_{w}}{r} & =F \\
\tau_{s} & =d F+M
\end{aligned}
$$

式（11）に，式（12），および非干渉化の設計条件式（6）を 代入することで, 各方向の力とスプロケットを回転させるトル クの関係は以下のように簡単な形式となって得られる.

$$
\left[\begin{array}{c}
\tau_{w s} \\
\tau_{s s}
\end{array}\right]=\left[\begin{array}{ll}
d & 0 \\
0 & 1
\end{array}\right]\left[\begin{array}{c}
F \\
M
\end{array}\right]
$$

式 (13) の右辺の行列は, その対角成分以外の要素が零であ り, 車輪の駆動力が操舵軸モー夕に伝達されないことを意味し ている。このように，車輪の駆動力により，操舵軸に不必要なト ルクが作用しないことから操舵軸駆動用のモー夕を小型化，お よび操舵軸の制御精度の向上が期待できる。

\section{2 同期駆動機構}

Fig. 5 に示す駆動機構において，車輪機構の静力学は車輪の 左右の配置にかかわらず基本的に同じ形態の式（13）にて表さ れることから, 車両の静力学はこれを車輪数だけ加算すればよ い. また，車両の中心に作用する車両の進行方向，および横方 向の力を $F_{x}, F_{y}$ とするとき, 各車輪の操舵軸に作用する力と それらの関係は以下のようになる。

$$
\begin{aligned}
& F_{x}=4\left(F \cos \theta_{s}-\frac{M}{s} \sin \theta_{s}\right) \\
& F_{y}=4\left(F \sin \theta_{s}+\frac{M}{s} \cos \theta_{s}\right)
\end{aligned}
$$


上式に車両本体の旋回トルク $T_{z}$ を付加することで, 車両全体 の静力学モデルが以下のように得られる.

$$
\begin{aligned}
{\left[\begin{array}{c}
\tau_{w m} \\
\tau_{s m} \\
\tau_{r m}
\end{array}\right] } & =\left[\begin{array}{cc:c}
\frac{d}{G_{w}} & 0 & 0 \\
0 & \frac{s}{G_{s}} & 0 \\
\hdashline 0 & 0 & \frac{1}{G_{r}}
\end{array}\right]\left[\begin{array}{ccc}
\cos \theta_{s} & \sin \theta_{s} & 0 \\
-\sin \theta_{s} & \cos \theta_{s} & 0 \\
0 & 0 & 1
\end{array}\right]\left[\begin{array}{c}
F_{x} \\
F_{y} \\
T_{z}
\end{array}\right] \\
\hdashline & {\left[\begin{array}{ccc}
\frac{d}{G_{w}} \cos \theta_{s} & \frac{d}{G_{w}} \sin \theta_{s} & 0 \\
-\frac{s}{G_{s}} \sin \theta_{s} & \frac{s}{G_{s}} \cos \theta_{s} & 0 \\
0 & 0 & \frac{1}{G_{r}}
\end{array}\right]\left[\begin{array}{c}
F_{x} \\
F_{y} \\
T_{z}
\end{array}\right] }
\end{aligned}
$$

ただし， $\tau_{w m}, \tau_{s m}, \tau_{r m}$ はそれぞれ車輪, 操舵, 旋回のモー タトルクであり, また, $G_{w}, G_{s}, G_{r}$ はそれぞれ車輪, 操舵, 旋回の動力伝達系の減速比である.

式 (15) の第一等式の右辺第一の行列の左上の $2 \times 2$ 行列は 車輪座標系におけるトルクの関係を表しており, その対角成分 以外の要素は零であることから, 車輪の回転, 操舵間の各卜ル クは互いに非干渉化されていることが分かる.

\section{6. 運動学シミュレーション}

本章では, 前章にて得られた運動学モデルに基づいたシミュ レーションにより，提案する車両の制御の有効性および運動の 様子を確認する.

\section{1 非干渉車輪機構}

非干涉機構を導入した結果, 操舵軸モー夕と, 車輪用モー夕 の非干涉化が実現できることを $4 ， 5$ 章にて確認した。ここで は, 実際の動作を行う際に, どの程度モー夕の性能を向上でき るかを検討する. Fig. 10 は従来のキャス夕型動輪機構の動作 で，初期姿勢を $179.5[\mathrm{deg}]$ から X 軸正方向への並進移動を行っ た場合のシミュレーションである。ただし，各パラメータは以 下の値を設定した.

$\begin{array}{ll}\text { 車輪半径 } r & : 50[\mathrm{~mm}] \\ \text { オフセット距離 } s & : 25[\mathrm{~mm}] \\ \text { 減速比 } G & : 2 \\ \text { 移動速度 } v_{x} & : 20[\mathrm{~mm} / \mathrm{sec}]\end{array}$

また，Fig. 11 は初期姿勢を $180.5[\mathrm{deg}]$ から同じ並進動作を 行ったものである. 車輪の進行方向に対して, $180[\mathrm{deg}]$ の初期 姿勢を境としてキャス夕の旋回する方向が逆になる。このとき， 車輪の動作は上下対称な運動を行うことが分かる。また，操舵 スプロケットの回転速度は極性が逆になるのみで, 最大速度, 加 速度の絶対值は等しくなる。一方, 車輪スプロケットの回転速 度は，操舵軸の速度干涉を除去するための操舵軸の速度の一定 の割合が加算されるため, 車輪の旋回の方向によって回転の様 子が異なり, 正負それぞれの最高速度, 加速度が変化すること が分かる。これより, 車輪用モー夕に必要とされる速度, 加速 度はおのおのの絶対値の最大值より決定できる。

Fig. 12 は, 非干渉キャス夕機構（左配置構造）の動作のシ ミュレーションである. 車輪半径 $r$, およびオフセット距離 $s$, お

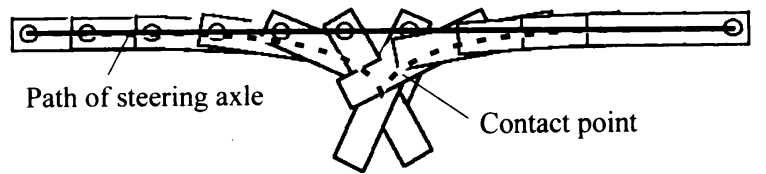

(a) Wheel motion

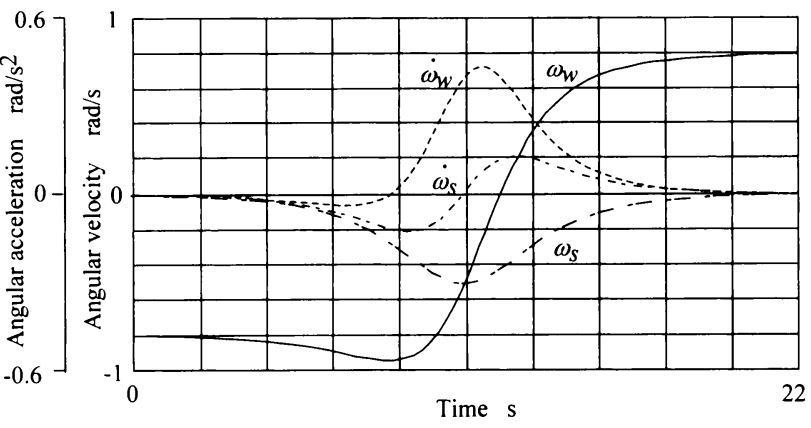

(b) Plots

Fig. 10 Drive caster simulation (Initial orientation 179.5deg)

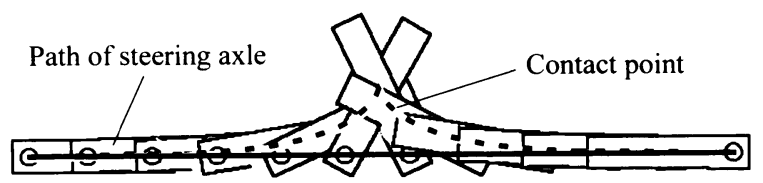

(a) Wheel motion

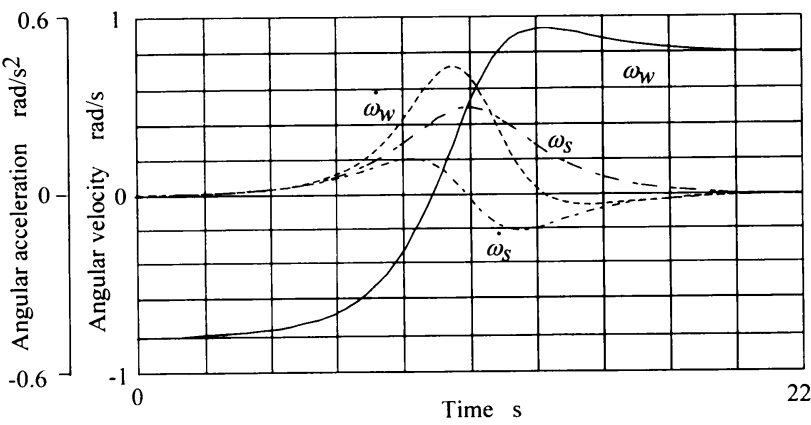

(b) Plots

Fig. 11 Drive caster simulation(Initial orientation 180.5deg)

よび車輪スプロケットから車輪軸までの減速比 $G$ は従来のキャ ス夕型動輪機構のシミュレーションと同様な値を設定した。 また, 非干渉化の条件式 (6) から横方向のオフセットは車輪半径, およ び減速比から必然的に決定される。この場合には $d=r / G=25$ となる. Fig. 13 は, 右配置構造の車輪のシミュレーション結 果である。これを Fig. 12 と比較すると, 車輪の速度, 加速度の 極性が逆になるのみであることが分かる。これより, Fig. 5 に 示すように輪スプロケットの回転方向を逆にすることで左右 異なる配置の車輪機構が混在した車両の複数車輪を単一のモー 夕により駆動可能であることが確認できる.

また, 通常のキャス夕型動輪機構の速度, 加速度の最大值を 非干涉キャス夕型動輪の場合と比較した結果, 減速比 $G=1$ の 場合, 最大速度は $59.1 \%$, また最大加速度は $30 \%, G=1.5$ の 場合最大速度は $30 \%$, 最大加速度は $14.9 \%, G=2$ の場合最 大速度は $17.9 \%$, 最大加速度は $9 \%$, それぞれ増加しているこ とが分かった。これより, 従来のキャス夕型動輪機構では $G$ を 


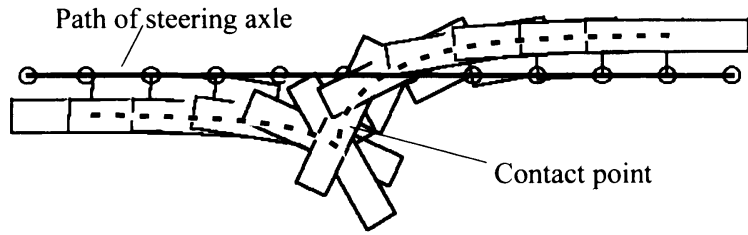

(a) Wheel motion

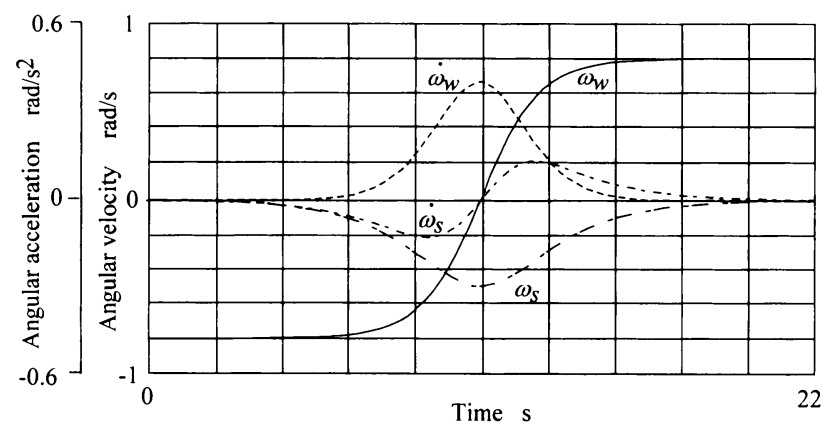

(b) Plots

Fig. 12 Decoupled drive caster simulation (Left config)

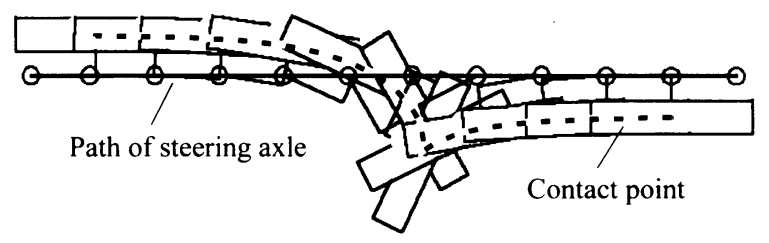

(a) Wheel motion

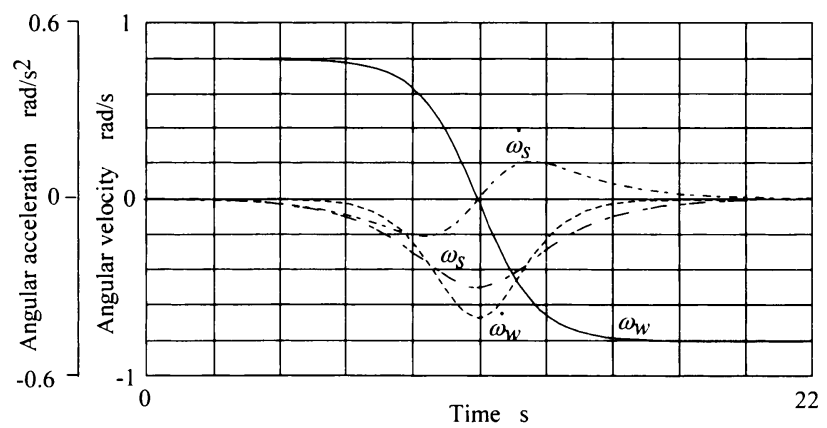

(b) Plots

Fig. 13 Decoupled drive caster simulation (Right config)

大きくすると，操舵軸の回転に対する車輪の回転の比が小さく なり速度干涉の度合いは緩和されることになる。しかし，車輪 用モータから操舵用モータのトルク干涉は， $G$ に比例して増大 することから操舵用モー夕の大容量化をまねく結果となる。こ れに対し, 非干渉化を施した車輪機構では, 車輪, 操舵のモ一 夕はそれぞれ独立に容量を決定することが可能である.

\section{24 輪車両}

同期キャスタ駆動方式による全方向移動車両のシミュレーショ ンを行ったＦig. 14 に結果を示す。これは，一定角速度にて 車両本体の旋回を行いながら, 横方向に等速直進運動を行う例 である，車両本体の最前部，および右配置，左配置の車輪の接 地点の軌跡が示されている. 車両の最前部が滑らかに移動して いる様子が分かる，これより，提案する機構により三つのモ一 夕にてホロノミック全方向移動が可能であることが確認できた。

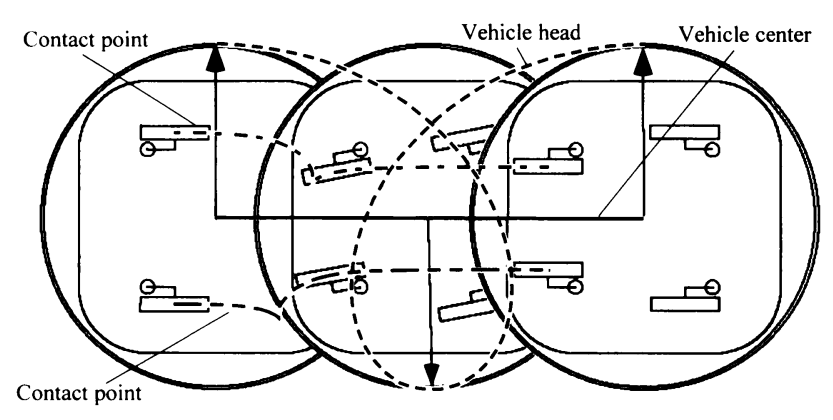

Fig. 14 Omnidirectional vehicle simulation

また，右左配置の異なる車輪スプロケットは同一のモータにて 駆動されているにもかかわらず，タイヤ自身の回転方向の切り 替わる時刻が異なることが分かった。この特性によりキャスタ 型車輪の欠点である車輪の回転方向の切り替え時に生じる走行 軌道の摇らぎが軽減できると考えられる。

\section{7. 結論}

ホロノミック全方向移動ロボットのための新しい車輪構造と して, キャスタ型動輪を同期駆動機構にて駆動する移動車両を 提案した。この車両は三つのモータで制御できるので過拘束の 問題を基本的に回避することができる。またキャス夕型の車輪 機構を用いることから通常の形態のタイヤを装着できる利点を 失うことなく，その車輪全輪を駆動輪とすることができる。こ の全方向移動車両では同期駆動機構にて車両の並進運動と旋回 運動の非干渉化を行い, さらにキャス夕型車輪に非干渉機構を 導入することで車輪軸と操舵軸の制御上の非干涉化を図った。 これらの非干渉機構の導入により, その運動学方程式は極めて 簡単なものとなり, 制御システムの計算負荷の軽減が期待でき る.また，非干渉車輪機構，および 4 輪車両についてその運動 学と静力学を解析し，その結果に基づき同期駆動機構における 車輪の設置方向を工夫することで, 各モー夕の無駄な出力を省 き, 効率の良い駆動が可能であることをシミュレーションによ り示した。

ここで検討した車両は, ホロノミックな移動特性の利点と, 従 来から蓄積されてきた移動ロボットベースの機構の利点を融合 するものである.非干渉車輪機構, 同期駆動機構とも, すでに 製品に適用されており，製造方法などは確立されている。これ ら春用段階の機構を用いることで，実用上の多くの問題を解決 するホロノミック移動車両の実現が可能となる.

\section{参 考 文 献}

[1] S. Mascaro, J. Spano and H.H. Asada: "A reconfigurable Holonomic Omnidirectional Mobile Bed with Unified Seating (RHOMBUS) for Bedridden Patients," IEEE Int. Conf. on Robotics and Automation, pp.1277-1282, 1997.

[2] P.F. Muir and N.E. Neuman: "Kinematic Modeling for Feedback Control of an Omni-directional Wheeled Mobile Robots," IEEE Int. Conf. on Robotics and Automation, pp.1772-1778, 1987

[ 3 ] 湯軍, 渡辺桂吾, 栗林勝利, 白石大和：“直交車輪機構を用いた全方 向移動ロボット車の自律制御”, 日本ロボット学会誌, vol.17, no.1, pp.51-60, 1999. 
[4] H.P. Moravec, Ed.,: "Autonomous Mobile Robots Annual Report - 1985," Robotics Institute Technical Report, Carnegie Mellon University, Pittsburgh, PA. , 1986.

[5] M. West and H. Asada: "Design and Control of Ball Wheel Omnidirectional Vehicles," IEEE Int. Conf. on Robotics and Automation, pp.1931-1938, 1995.

[6] H. Asama, M. Sato, L. Bogoni, et. al: "Development of an Omni-Directional Mobile Robot with 3 DOF Decoupling Mechanism," IEEE Int. Conf. on Robotics and Automation, pp.1925-1930, 1995.

[ 7 ] S. Hirose and S. Amano: "The VUTON: High Payload High Efficiency Holonomic Omni-Directional Vehicle," 6th Int. Symp. on Robotics Research, 1993.

[8] F.G. Pin and S.M. Killough: "A New Family of Omnidirectional and Holonomic Wheeled Platforms for Mobile Robots," IEEE Transactions on Robotics and Automation, vol.10, no.4, pp.480-489, 1994

[9] L. Ferriere, B. Raucent and G. Campion: "Design of Omnimobile Robot Wheels," 1996 IEEE Int. Conf. on Robotics and Automation, pp.3664-3670, 1996.

[10] 和田正義, 森俊二: “ホロノミック全方向移動ロボットの開発”, 日本 ロボット学会誌, vol.15, no.8, pp.1139-1146, 1997.

[11] 川田辰実, 森俊二, 高木昭, 奥澤好之, 和田正義：“二輪速度差ユニッ トを二組用いた全方向移動車両の開発”, 第 15 回日本ロボット学会 学術講演会予稿集, pp.837-838, 1997.

[12] F. Han, T. Yamada, K. Watanabe, K. Kiguchi and K. Izumi: "Construction of an Omnidirectional Mobile Robot Platform Based on Active Dual-Wheel Caster Mechanisms and Development of a Control Simulator," J. of Intelligent and Robotic Systems, vol.29, no.3, pp.257-275, 2000.

[13] H. Yu, S. Dubowsky and A. Skwersky: "Omni-directional Mobility using Active Split Offset Casters," ASME Design Engineering Technical Conference, 2000.

[14] R. Holombarg and O. Khatib: "Development of a Holonomic Mobile Robot for Mobile Manipulation Tasks," Int. Conf. on

Field and Service Robotics, 1999.

[15] 高木昭, 森俊二, 川田辰実, 奥澤好之, 和田正義：“二輪速度差二ニッ トと旋回軸による全方向移動車両の開発”, 第 15 回日本ロボット学 会学術講演会予稿集, pp.839-840, 1997.

[16] M.J. Jung, H.S. Shim, H.S. Kim and J.H. Kim: "The Miniature Omni-directional Mobile Robot OmniKity-I (OK-I)," IEEE Int. Conf. on Robotics and Automation, pp.2686-2691, 1999.

[17] 森信人，家田純一，関森大介，升谷保博，宮崎文夫：“全方位視覚と 全方向移動能力を有する小型サッカーロボット”，第 17 回日本ロボッ 卜学会学術講演会予稿集, pp.553-554, 1999.

[18] Mobile Robots "B21r" and "B14r," Real World Interface, 32 Fitzgerald Drive Jaffrey, NH03452, USA.

[19] E. Nakano and N. Koyachi: "An Advanced Mechanism of the Omni-Directional Vehicle (ODV) and Its Application to the Working Wheelchair for the Disabled," Int. Conf. on Advanced Robotics, pp.277-284, 1983.

[20] 轟英一, 横井一仁, 小森谷清, 村田良司：“屋内環境移動プラットフォー ムの開発と姿勢安定化のための移動制御法”，日本機械学会ロボティ クス・メカトロニクス講演会 2000，2P2-41-052.

[21] M. Wada, A. Takagi and S. Mori: "Caster Drive Mechanism for Holonomic and Omnidirectional Mobile Platforms with no Over Constraint," IEEE Int. Conf. on Robotics and Automation, pp.1531-1538, 2000

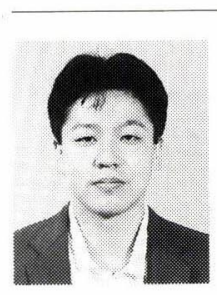

の会員.
和田正義 (Masayoshi Wada)

1965 年 8 月 2 日生. 1990 年東京理科大学工学部一 部機械工学科卒業. 同年富士電機 (株) 人社. 1996 1998 年マサチューセッツ工科大学, 機械工学科に て客員研究員. 現在, (株) 富士電機総合研究所, 機 器技術研究所所属. 点検ロボット，移動ロボット等 のメカトロニクス機器の開発, 設計に従事. IEEE

(日本ロボット学会正会員) 